\title{
The development of a three-frame timeline for clinical concepts extracted from discharge summaries
}

\author{
Christopher Burton ${ }^{*}$, Sujin Kim² \\ From 11th Annual UT-ORNL-KBRIN Bioinformatics Summit 2012 \\ Louisville, KY, USA. 30 March - 1 April 2012
}

\section{Background}

Through the functional presentation of information, natural language processing (NLP) of electronic medical records (EMR) improves efficiency in the clinical research and patient care domains. Discharge summary NLP, when utilized to associate clinical concepts with temporal references, conveys the order of events related to an admission.

\section{Materials and methods}

Utilizing Knowtator, a schema was designed to relate clinical concepts within discharge summary sections, including disease states, procedures, lab results, and medications, to a timeline. The timeline was defined by three frames: PreAdmission, Hospital Stay, and Post-Discharge. Fifty-five discharge summaries from the i2b2 NLP Challenge were randomly selected for review. Clinical concepts were manually extracted, categorized within the appropriate frame, and compared to the MetaMAP and YTEx systems to establish a gold standard. It was observed that concepts in the same section correlated to the same frame in the timeline. Additionally, the frame was determined through the classification of section titles. The same method could be further refined to associate clinical concepts with more specific date and time markers, leading to a comprehensive view of the medical timeline.

\footnotetext{
Author details

'Department of Computer Science, Eastern Kentucky University, Richmond,

KY 40475, USA. ${ }^{2}$ Division of Biomedical Informatics, Department of

Biostatistics, University of Kentucky, Lexington, KY 40506, USA.

Published: 31 July 2012

* Correspondence: Christopher.burton@uky.edu

'Department of Computer Science, Eastern Kentucky University, Richmond, KY 40475, USA

Full list of author information is available at the end of the article
}

doi:10.1186/1471-2105-13-S12-A14

Cite this article as: Burton and Kim: The development of a three-frame timeline for clinical concepts extracted from discharge summaries. BMC Bioinformatics 2012 13(Suppl 12):A14.
Submit your next manuscript to BioMed Central and take full advantage of:

- Convenient online submission

- Thorough peer review

- No space constraints or color figure charges

- Immediate publication on acceptance

- Inclusion in PubMed, CAS, Scopus and Google Scholar

- Research which is freely available for redistribution

Submit your manuscript at www.biomedcentral.com/submit

\section{() Biomed Central}

C Biomed Central

(C) 2012 Burton and Kim; licensee BioMed Central Ltd. This is an Open Access article distributed under the terms of the Creative Commons Attribution License (http://creativecommons.org/licenses/by/2.0), which permits unrestricted use, distribution, and reproduction in any medium, provided the original work is properly cited. 